\title{
DESAIN DAN UJI COBA LEMBAR KERJA PESERTA DIDIK (LKPD) KIMIA BERBASIS PROBLEM SOLVING PADA MATERI KOLOID
}

\author{
Vulva Fitrah ${ }^{1)}$, Arif Yasthophi ${ }^{2)}$ \\ 1) Program Studi Pendidikan Kimia Fakultas Tarbiyah dan Keguruan \\ Universtas Islam Negeri Sultan Syarif Kasim Riau, Indonesia \\ Email vulvafitrah@gmail.com \\ 2) Program Studi Pendidikan Kimia Fakultas Tarbiyah dan Keguruan \\ Universtas Islam Negeri Sultan Syarif Kasim Riau, Indonesia \\ Email arifyasthophi@gmail.com
}

\begin{abstract}
This research is motivated by the lack of understanding of students on colloidal concepts in chemistry learning and the absence of chemistry student workbook based problem solving. In this study a chemistry student workbook based problem solving design was designed to support learning in colloid lesson. It was a Research and Development (R\&D) method with Borg and Gall design. This research was administrated at State Senior High School 1 Salo. Subject of this research were Media design experts, Learning lesson experts, chemistry teachers and tenth student at the tweleve grade of MIPA. Object of this research were chemistry student workbook based problem solving on colloid lesson. The instruments of this research were questionnaire of validity test by the experts and questionnaire of practicality test by teacher and students. Student workbook was good if it was valid and practice aspect quality. Validity and practicality could be seen from the result of validity and practicality by using validity and practicalities sheets. The level percentage of validity was $91.5 \%$ (Very valid) and level of practicality was $87.72 \%$ (Very practice). From the identifiy result that student workbook testing was good and practice to be an additional teaching material for teachers at school.
\end{abstract}

\section{Keywords : Student Workbook, Problem Solving Approach, Colloid}

\section{PENDAHULUAN}

Kimia adalah cabang Ilmu Pengetahuan Alam (IPA) yang secara khusus mempelajari tentang struktur, susunan, sifat dan perubahan materi serta energi yang menyertai perubahannya. Seseorang yang mempelajari kimia tidak hanya membutuhkan keterampilan saja, tetapi juga diperlukan proses berfikir untuk memahami, menemukan, mengembangkan konsep, teori dan hukum serta pemecahan masalah dalam kehidupan seharihari. Pembelajaran kimia merupakan salah satu pembelajaran IPA yang dalam prosesnya melibatkan peran peserta didik untuk memahami suatu konsep kimia. Pemahaman peserta didik terhadap konsep kimia dapat dibentuk melalui keaktifan peserta didik dalam proses "mencari tahu" dan "berbuat" seperti kegiatan eksperimen atau demonstrasi yang dapat membantu peserta didik dalam mengkonstruksikan pengetahuan yang dimilikinya.[1]

Pemahaman peserta didik terhadap suatu konsep kimia tidak mudah tercapai dengan sendirinya tanpa adanya upaya dan fasilitas yang didesain khusus dalam pembelajaran. Salah satu upaya yang dapat dilakukan yaitu dengan mendesain bahan ajar berupa LKPD yang mampu menfasilitasi pemahaman konsep peserta didik.[2]

Lembar Kerja Peserta Didik (LKPD) adalah suatu bahan ajar cetak berupa lembarlembar kertas yang berisi materi, ringkasan dan petunjuk-petunjuk pelaksanaan tugas pembelajaran yang harus dikerjakan oleh peserta didik, yang mengacu pada kompetensi dasar yang harus dicapai.[3] Secara umum, LKPD merupakan perangkat pembelajaran sebagai pelengkap atau sarana pendukung pembelajaran. LKPD biasanya berupa petunjuk dan langkah-langkah untuk menyelesaikan suatu tugas.[4] LKPD lebih sederhana daripada 
modul, namun lebih kompleks daripada buku. LKPD terdiri atas enam unsur utama, meliputi: judul, petunjuk belajar, kompetensi dasar atau materi pokok, informasi pendukung, tugas atau langkah-langkah kerja dan penilaian .[5] LKPD sebagai bahan ajar dalam pembelajaran dapat digunakan untuk menyampaikan materi kimia salah satunya pada materi koloid.

Koloid adalah salah satu dari materi pembelajaran kimia. Koloid ialah campuran dari dua atau lebih zat yang salah satu fasanya tersuspensi sebagai sejumlah besar partikel yang sangat kecil dalam fasa kedua.[6] Materi koloid merupakan materi yang tidak hanya memerlukan pemahaman hafalan, tetapi juga pemahaman konsep agar peserta didik lebih mudah memahami, mengingat, dan menjawab soal-soal latihan yang ada didalam LKPD.

Materi koloid ini berhubungan secara langsung dengan kehidupan sehari-hari peserta didik. Sehingga peserta didik dituntut untuk mengetahui hubungan materi pembelajaran dengan kehidupan sehari-hari. Dengan dipilihnya koloid yang dimuat didalam LKPD peserta didik dapat mengetahui hubungan koloid dengan kehidupan sehari-hari. Karena berdasarkan hasil wawancara dengan guru kimia SMA Negeri 1 Salo, pada saat mengajar peserta didik cenderung kurang mampu menghubungkan antara materi koloid dengan kehidupan sehari-hari. Dengan didesainnya LKPD kimia berbasis problem solving ini diharapkan dapat membantu peserta didik dalam menghubungkan pembelajaran kimia dengan kehidupan sehari-hari dan melatih keterampilan peserta didik dalam memecahkan masalah dengan baik.

LKPD perlu didesain secara menarik agar dapat merangsang peserta didik untuk tertarik belajar dan dapat dimanfaatkan secara mandiri oleh peserta didik. Pengembangan bahan ajar LKPD sangat diperlukan dalam proses pembelajaran untuk memudahkan pencapaian tujuan pembelajaran yang diharapkan. Keunggulan dari LKPD adalah dapat didesain sesuai dengan keadaan peserta didik dan karakteristik sekolah.[7] Desain perangkat LKPD yang baik sangat dibutuhkan agar tercapainya proses pembelajaran yang mendorong peserta didik lebih berperan aktif.[8] Dengan adanya LKPD, peserta didik dapat didorong untuk menyelesaikan tugastugas yang terdapat didalam LKPD. Penyajian LKPD dapat dikembangkan dengan berbagai macam inovasi, salah satu diantaranya yaitu memadukan LKPD dengan model pembelajaran problem solving. [9]

Model pembelajaran problem solving adalah suatu penyajian materi pembelajaran dengan menghadapkan peserta didik pada persoalan yang harus dipecahkan atau diselesaikan untuk mencapai tujuan pembelajaran.[10] Model pembelajaran problem solving ini dapat membuat peserta didik berpikir kreatif dalam mengerjakan soalsoal yang diberikan guru, sehingga peserta didik tidak terpaku hanya dari informasi yang didapatkan dari guru saja. Melalui model pembelajaran ini dapat membiasakan peserta didik menghadapi dan memecahkan masalah secara terampil. Model ini juga merangsang pengembangan kemampuan berpikir peserta didik secara kreatif dan menyeluruh, karena dalam proses belajarnya peserta didik banyak melakukan mental dengan menyoroti permasalahan dari berbagai segi dalam rangka mencari pemecahan masalah.[11]

Berdasarkan hasil wawancara yang diperoleh dari salah satu guru mata pelajaran kimia di SMA Negeri 1 Salo, beliau mengatakan bahwa di sekolah tersebut tidak pernah menggunakan LKPD. Proses pembelajaran peserta didik difasilitasi bahan ajar berupa buku paket yang telah disediakan oleh pihak sekolah. Guru menjelaskan materi pelajaran secara langsung tanpa adanya proses mencari tahu serta jarang mengaitkan materi pelajaran dengan kehidupan sehari-hari. Sehingga peserta didik kurang terlibat secara aktif dalam proses pembelajaran. Peserta didik cenderung hanya menerima materi dari guru, akibatnya peserta didik malas untuk berfikir mandiri.

Oleh karena itu, peneliti memandang bahwa diperlukan suatu bahan ajar yang dapat mempermudah peserta didik dalam memahami pelajaran, meningkatkan kualitas pembelajaran dalam mencapai tujuan pembelajaran kimia. Dengan didesainnya LKPD kimia berbasis problem solving diharapkan peserta didik dapat mengikuti proses pembelajaran dengan baik. Serta dapat melatih kemampuan peserta didik untuk memecahkan permasalahan dalam pembelajaran bahkan dalam kehidupan seharihari.

Berdasarkan uraian diatas, penulis tertarik untuk melakukan penelitian dengan judul "Desain dan Uji Coba Lembar Kegiatan Peserta Didik (LKPD) Kimia Berbasis Problem Solving pada Materi Koloid". 


\section{METODE PENELITIAN}

Jenis penelitian ini digolongkan kedalam penelitian pengembangan (Research and Development) dengan menggunakan model pengembangan Borg and Gall yang terdiri dari sepuluh tahapan yaitu pengumpulan data, perencanaan, pengembangan draf produk, uji coba lapangan awal, revisi produk awal, uji coba lapangan, penyempurnaan produk hasil uji coba lapangan, uji pelaksanaan lapangan, penyempurnaan produk akhir, diseminasi dan implementasi. Namun, pada penelitian ini hanya sampai pada tahap ke lima yaitu revisi produk awal. Penelitian ini untuk menghasilkan LKPD yang akan divalidasi dan diujicobakan terbatas. Penelitian ini dilakukan di SMA Negeri 1 Salo dengan subjek penelitian sebanyak 10 orang peserta didik kelas XII MIPA.

Instrumen penelitian yang digunakan adalah angket validasi oleh ahli media, angket validasi ahli materi, angket praktikalitas guru, dan angket respon peserta didik. Validasi digunakan untuk mengetahui hasil validasi LKPD yang dinilai oleh 2 orang dosen pendidikan kimia, dimana 1 orang merupakan ahli media, dan 1 orang lagi merupakan ahli materi. Praktikalitas guru dan respon peserta didik digunakan untuk melihat bagaimana tanggapan guru dan peserta didik terhadap kemenarikan dan kemudahan dalam memahami LKPD yang didesain. Data diperoleh dari hasil angket validasi, praktikalitas dan respon peserta didik. Analisis data hasil validasi dan praktikalitas dilakukan terhadap setiap aspek dalam lembar angket. Skor data hasil angket diperoleh berdasarkan rating scale dengan kisaran skor 1 sampai 5. Kriteria penskoran sebagai berikut : skor 1 (tidak baik), 2 (kurang baik), 3 (cukup baik), 4 (baik), dan 5 (sangat baik). Skor dikonversikan dengan menggunakan persamaan;

$$
\text { Persentase }=\frac{\text { skor yang diperoleh }}{\text { skor maksimal }} \times 100 \%
$$

Adapun kriteria interpretasi nilai dari angket validasi, praktikalitas guru, dan respon peserta didik terhadap LKPD sebagai berikut:
Tabel I. Kriteria hasil angket validasi terhadap LKPD [12]

\begin{tabular}{lll}
\hline No. & Persentasi $(\%)$ & Kriteria \\
\hline 1. & $80 \leq$ Nilai $\leq 100$ & Sangat valid \\
2. & $60 \leq$ Nilai $<80$ & Valid \\
3. & $40 \leq$ Nilai $<60$ & Cukup valid \\
4. & $20 \leq$ Nilai $<40$ & Kurang valid \\
5. & $0 \leq$ Nilai $<20$ & Tidak valid \\
\hline
\end{tabular}

Tabel II. Kriteria hasil angket praktikalitas guru dan respon peserta didik terhadap LKPD

\begin{tabular}{lll}
\hline No. & Persentasi (\%) & Kriteria \\
\hline 1. & $80 \leq$ Nilai $\leq 100$ & Sangat praktis \\
2. & $60 \leq$ Nilai $<80$ & Praktis \\
3. & $40 \leq$ Nilai $<60$ & Cukup praktis \\
4. & $20 \leq$ Nilai $<40$ & Kurang praktis \\
5. & $0 \leq$ Nilai $<20$ & Tidak praktis \\
\hline
\end{tabular}

\section{HASIL DAN PEMBAHASAN}

Produk yang didesain dalam penelitian ini berupa Lembar Kerja Peserta Didik (LKPD) kimia berbasis problem solving pada materi koloid. LKPD ini didesain oleh peneliti agar dapat menjadi bahan ajar yang dapat membantu guru dalam proses pembelajaran dan sebagai salah satu sumber belajar bagi peserta didik baik di kelas maupun di rumah.

Lembar Kerja Peserta Didik (LKPD) kimia berbasis problem solving pada materi koloid dikembangkan dengan menggunakan prosedur pengembangan menurut Borg and Gall yang disederhanakan sesuai kebutuhan penelitian menjadi lima tahap. Data hasil setiap tahapan yang dilakukan adalah sebagai berikut:

\section{a. Tahap Pengumpulan Data}

Tahap pengumpulan data dilakukan untuk mengetahui kebutuhan peserta didik terhadap produk yang dikembangkan. Tahap pengumpulan data dilakukan dengan cara studi lapangan dan studi pustaka. Studi lapangan dilakukan dengan cara melakukan analisis kurikulum dan analisis ketersediaan media pembelajaran dilapangan.

Tahap ini dilakukan melalui proses wawancara dengan guru mata pelajaran kimia di SMA Negeri 1 Salo. Wawancara dilakukan untuk mengetahui ketersedian Lembar Kerja Peserta Didik (LKPD) dan proses pembelajaran yang sedang berlangsung, serta analisis terhadap 
ketertarikan peserta didik dalam pembelajaran kimia dan bahan ajar yang digunakan di sekolah. Berdasarkan hasil wawancara didapatkan informasi bahwa guru memerlukan suatu bahan ajar dan metode yang tepat sehingga dapat membantu proses pembelajaran agar peserta didik lebih tertarik untuk belajar kimia dan lebih mandiri, kreatif dalam berfikir serta lebih berperan aktif dalam proses pembelajaran.

Desain LKPD dapat didukung dengan suatu pendekatan atau model pembelajaran yang sesuai, sehingga manfaat penggunaan LKPD dalam pembelajaran akan lebih optimal. Pendekatan yang digunakan dalam LKPD yang dihasilkan peneliti yaitu dengan menggunakan pendekatan problem solving, pemilihan pendekatan tersebut mengacu pada hasil penelitian yang menunjukkan bahwa pembelajaran dengan menggunakan pendekatan problem solving dapat meningkatkan kemampuan belajar peserta didik dibandingkan dengan pembelajaran konvensional dan dapat meningkatkan keaktifan peserta didik.[13]

Selanjutnya yaitu studi pustaka yang dilakukan dengan cara mengumpulkan informasi dari jurnal maupun buku yang berkaitan dengan desain dan uji coba Lembar Kerja Peserta Didik (LKPD) kimia berbasis problem solving pada materi koloid.

\section{b. Tahap Perencanaan}

Setelah dilakukan pengumpulan data selanjutnya adalah perencanaan produk. Ada beberapa hal yang dilakukan pada tahap perencanaan yaitu menyesuaikan standar kompetensi dan kompetensi dasar serta silabus berdasarkan kurikulum 2013. Produk dari penelitian ini berupa LKPD kimia berbasis problem solving yang dirancang pada materi koloid yang terdapat pada kelas XI KD 3.13 dan 4.14. Sub topik yang diambil meliputi: jenis-jenis koloid, sifatsifat koloid, pembuatan koloid, dan peranan koloid. LKPD dirancang untuk 4 kali pertemuan. Masing-masing pertemuan memiliki sub topik yang berbeda-beda. Pada pertemuan pertama sub materi mengenai jenis-jenis koloid, pada pertemuan kedua LKPD memuat sub materi sifat-sifat koloid, pada pertemuan ketiga LKPD memuat sub materi pembuatan koloid, dan pada pertemuan keempat LKPD memuat sub materi peranan koloid. Setiap LKPD yang dikembangkan memuat langkah-langkah pendekatan problem solving.

LKPD dibuat dengan menggunakan Microsoft Word 2007 dengan berbagai variasi warna, gambar, ukuran. LKPD berbasis problem solving pada materi koloid menggunakan kertas A4, skala spasi 1,15, jenis tulisan Berlin Sans FB serta menggunakan shape. LKPD dilengkapi dengan rangkuman materi dan beberapa contoh soal mengenai materi koloid.

Tujuan dari penggunaan produk lembar kerja peserta didik (LKPD) kimia berbasis problem solving yaitu untuk membantu peserta didik dalam memahami konsep koloid dan sebagai referensi dalam memecahkan semua permasalahan yang berhubungan dengan materi koloid. Pengguna dari produk ini adalah guru kimia dan peserta didik kelas XI SMA/MA. Komponen dari produk ini terdiri dari tiga bagian yaitu: (1). Pendahuluan terdiri dari: cover, kata pengantar, daftar isi, deskripsi singkat, petunjuk penggunaan LKPD, Kompetensi Inti (KI), Kompetensi Dasar (KD), indikator dalam pembelajaran, tahapan problem solving, dan peta konsep. (2) Bagian isi yang terdiri dari tiga kegiatan pembelajaran. Kegiatan 1: jenis-jenis koloid, kegiatan 2: sifat-sifat koloid, kegiatan 3: pembuatan koloid, kegiatan 4: peranan koloid, dan (3) bagian penutup berisi rangkuman dan daftar pustaka.

\section{c. Tahap Pengembangan Produk}

Sebelum melakukan pembuatan LKPD peneliti menentukan desain atau konsep LKPD yang akan dikembangkan dengan cara menyusun draf LKPD kimia berbasis problem solving pada materi koloid. Pada tahap ini didesain bagian-bagian dari LKPD yaitu cover, kata pengantar, daftar isi, bagian pendahuluan meliputi deskripsi singkat, petunjuk penggunaan LKPD, Kompetensi Inti (KI), Kompetensi Dasar (KD), indikator, tahapan problem solving, dan peta konsep, bagian isi meliputi materi dan latihan-latihan soal, serta bagian penutup yang meliputi rangkuman dan daftar pustaka. 


\section{d. Uji Coba Terbatas}

Pada tahap uji coba terbatas, LKPD di validasi oleh ahli media dan ahli materi. Validasi oleh ahli media dan ahli materi ini bertujuan untuk mendapatkan LKPD kimia yang valid dan praktis. Setelah LKPD di validasi oleh ahli media dan ahli materi, LKPD di uji kepraktisannya oleh guru guna mengetahui tingkat kepraktisan LKPD yang didesain. Setelah itu, LKPD diujicobakan pada peserta didik guna mengetahui respon peserta didik terhadap LKPD yang didesain. Pada langkah ini pengumpulan dan analisis data dapat dilakukan dengan cara wawancara dan angket.

\section{1) Validasi oleh Ahli Media}

Validasi ahli media bertujuan untuk menilai penyajian LKPD kimia berbasis problem solving pada materi koloid. Adapun validator yang menjadi ahli media terdiri dari 1 dosen pendidikan kimia UIN SUSKA Riau. Berdasarkan hasil perhitungan angket validasi ahli media, LKPD kimia berbasis problem solving pada materi koloid dikatakan sangat valid dengan persentasi penilaian sebesar $93,84 \%$.

\section{2) Validasi oleh Ahli Materi}

Produk yang telah selesai dikembangkan, kemudian divalidasi oleh ahli materi. Validasi ahli materi bertujuan untuk menilai kelengkapan materi, kebenaran materi, dan sistematika materi. Adapun validator yang menjadi ahli materi terdiri dari 1 orang dosen pendidikan kimia UIN SUSKA Riau. Ahli materi diminta untuk mengisi angket penilaian serta memberikan kritik dan saran untuk perbaikan produk. LKPD kimia berbasis problem solving pada materi koloid dikatakan sangat valid dengan persentasi penilaian sebesar $89,16 \%$. Selanjutnya LKPD ini dinilai oleh guru.

\section{3) Praktikalitas LKPD oleh Guru Kimia}

Setelah divalidasi oleh ahli media dan ahli materi, selanjutnya LKPD diuji kepraktisannya oleh guru kimia di SMA Negeri 1 Salo. Uji coba guru ini dilakukan untuk meyakinkan data dan mengetahui kemenarikan produk secara luas. Responden pada uji praktikalitas guru ini berjumlah 2 orang. Berdasarkan hasil penilaian angket hasil rata-rata praktikalitas yang diperoleh sebesar $87,72 \%$ dan termasuk kedalam kriteria sangat praktis serta layak diujicobakan di SMA Negeri 1 Salo.

\section{4) Respon Peserta Didik Terhadap LKPD}

Setelah LKPD diujicobakan kepada 2 guru di SMA Negeri 1 Salo. Selanjutnya peserta didik memberikan penilaian terhadap LKPD kimia berbasis problem solving pada materi koloid yang didesain oleh penulis. Penilaian ini dilakukan oleh 10 orang peserta didik kelas XI MIPA 1 SMA Negeri 1 Salo. Hasil rata-rata penilaian peserta didik terhadap LKPD kimia berbasis problem solving pada materi koloid mendapat respon yang baik dari peserta didik.

\section{e. Revisi Produk Awal}

Setelah desain produk divalidasi melalui penilaian dari ahli media, ahli materi, dan guru kimia di SMA Negeri 1 Salo, peneliti melakukan revisi terhadap desain produk yang dikembangkan berdasarkan masukan-masukan dari ahli tersebut. Berdasarkan kritik dan saran dari ahli media, didapatkan saran perbaikan produk yaitu mengenai jenis huruf, ukuran huruf, warna huruf, spasi, tanda baca, konsistensi dalam penulisan, desain yang digunakan, layout, keterangan gambar.

Berdasarkan kritik dan saran dari ahli materi, LKPD kimia berbasis problem solving ini perlu direvisi mengenai tujuan pembelajaran dan materi koloid didalam LKPD. Maka berdasarkan saran yang diberikan LKPD sudah diperbaiki.

\section{SIMPULAN}

Berdasarkan hasil penelitian dan pembahasan, maka dapat diambil beberapa simpulan yaitu :

1. Penelitian menggunakan desain penelitian Borg and Gall yang meliputi: pertama tahap pengumpulan data, dimana pada tahap ini diperoleh hasil 
bahwa peserta didik memerlukan bahan ajar yang dapat mendukung pemahaman konsep berdasarkan analisis kurikulum dan analisis berbagai referensi buku. Kedua tahap perencanaan, tahap ini menghasilkan rancangan desain dalam bentuk prototype LKPD. Ketiga tahap pengembangan draf produk, dalam tahapan ini menghasilkan produk LKPD kimia berbasis problem solving. Keempat tahap uji coba terbatas, dalam tahapan ini LKPD di validasi oleh ahli media dan ahli materi. Kelima tahap revisi produk awal, dalam tahapan ini peneliti melakukan revisi terhadap desain produk yang dikembangkan berdasarkan masukan-masukan dari ahli media dan ahli materi.

2. LKPD kimia berbasis problem solving dan pada materi koloid dinyatakan valid oleh desain media dan ahli materi pembelajaran dengan kategori sangat valid yaitu dengan presentase $91,5 \%$. Hasil ini terlihat dari presentase rata-rata analisis ahli media dan ahli materi pembelajaran berturut-turut yaitu $93,84 \%$ dan $89,16 \%$. LKPD kimia berbasis problem solving pada materi koloid dinyatakan praktis oleh guru kimia dengan presentase $87,72 \%$ dan mendapat respon yang baik dari peserta didik.

\section{REFERENSI}

[1] Abdurrohim, Tonih Feronika, dan Evi Sapinatul Bahriah, Pengembangan Lembar Kegiatan Siswa (LKS) Berbasis Inkuiri Terbimbing Pada Materi Hidrolisis Garam (Jakarta: Jurnal Penelitian dan Pembelajaran IPA (JPPI), Vol. 2, No. 2, ISSN: 2477-2038, Desember 2016), hlm. 198

[2] Fitriani, M. Hasan, dan Musri, Pengembangan Lembar Kegiatan Peserta Didik (LKPD) Berbasis Masalah untuk Meningkatkan Pemahaman Konsep dan Aktivitas Belajar Peseta Didik pada Materi Larutan Penyangga (Banda Aceh: Jurnal Pendidikan Sains Indonesia, Vol. 04, No. 02, 2016), hlm. 25

[3] Siti Syarifah, Pengembangan Lembar Kerja Peserta Didik (LKPD) Berorientasi Nilai-Nilai Agama Islam Melalui Pendekatan Inquiri Terbimbing Materi Trigonometri (Skripsi:
Universitas Islam Negeri Raden Intan Lampung, 2017), hlm.16

[4] Abdul Majid, Perencanaan Pengembangan Standar Kompetensi Guru (Bandung: PT Remaja Rosdakarya, 2008), hlm. 176

[5] Andi Prastowo, Panduan Kreatif Membuat Bahan Ajar Inovatif (Jogjakarta: Diva Press, 2011), hlm. 215

[6] David W. Oktoby, Prinsip-prinsip Kimia Modern (Jakarta: Erlangga, 1999), hlm. 178

[7] Asnaini, Adlim, dan Mahidin, Pengembangan LKPD Berbasis Pendekatan Scientific untuk Meningkatan Hasil Belajar dan Aktivitas Peserta Didik pada Materi Larutan Penyangga (Banda Aceh: Jurnal Pendidikan Sains Indonesia, Vol. 4, No. 2, 2016), hlm. 193

[8] Haris Munandar, Yusrizal, dan Mustanir, Pengembangan Lembar Kerja Peserta Didik (LKPD) Kimia Berorientasi Nilai Islami pada Materi Hidrolisis Garam (Banda Aceh: Jurnal Pendidikan Sains Indonesia, Vol. 3, No. 1, 2015), hlm. 29

[9] Lilis Nurliawaty, Mujasam, Irfan Yusuf, Sri Wahyu Widyaningsih, Lembar Kerja Peserta Didik (LKPD) Berbasis Problem Solving Polya (Papua: Jurnal Pendidikan Indonesia, Vol. 6, No. 1, ISSN: 25417207, 2017), hlm. 74

[10] Diana Novratilova, Nina Kadaritna, Lisa Tania, Efektivitas Problem Solving Dalam Meningkatkan Keterampilan Mengelompokkan Dan Menyimpulkan Pada Asam Basa (Lampung: Jurnal Pendidikan dan Pembelajaran Kimia, Vol. 4, No. 3 Edisi Desember 2015), hlm. 784

[11] Syaiful Bahri Djamarah, Strategi Belajar Mengajar (Jakarta: Rineka Cipta, 2006), hlm. 92

[12] Riduwan, Skala Pengukuran VariabelVariabel Penelitian, (Bandung: Alfabeta, 2007), hlm. 15.

[13] Lambertus., Bey, A., Anggo, M., Fahinu., Sudia, M., dan Kadir, Developing Skills Resolution Mathematical Primary School Students. (International Journal of Education and Research, ISSN: 2201-6333, Vol. 2, No. 10, 2014), hlm. 608 